\title{
Voters' responsiveness to public employment policies
}

\author{
Marta Curto-Grau*
}

October 14, 2016

\begin{abstract}
This paper examines the electoral rewards for the distribution of public employment. We focus on the Spanish Plan for Rural Employment, a public jobs program introduced by the central government in two lagging regions. We evaluate voters' responsiveness to this policy using municipal-level electoral data and employ an estimator that combines difference-in-differences with propensity score matching. The main findings are that the program lead to an increase in the vote share for the ruling party in the treated municipalities. This effect is very persistent over the years, and it is unlikely to be explained by turnout buying.

Keywords: redistribution, public employment, electoral rewards, difference-in-differences matching estimator.

JEL classification: H53 P16.
\end{abstract}

* University of Heidelberg and IEB. E-mail address: marta.curto@awi.uni-heidelberg.de. 


\section{Introduction}

In an attempt to transfer wealth from rich to poor individuals or groups, governments rely on a broad set of redistributive policies, such as taxation, targeted monetary transfers, and equalization grants. Although the ultimate goal of these policies is a reduction in wealth inequality, in some cases political consequences can also explain their adoption. The present paper focuses on the political effects of a particular type of redistributive policy, namely, public employment programs. Such programs are implemented in developed and developing countries. In Italy, for instance, public employment has been used as a subsidy from the wealthier North to the (relatively poorer) South (Alesina et al. 2001). ${ }^{1}$ In US cities with greater income inequalities and ethnic fragmentation, public employment is higher (Alesina et al. 2000). ${ }^{2}$ Other examples of this type of intervention are the Mahatma Gandhi National Rural Employment Guarantee Act (in India), Trabajo por Uruguay (a component of the Uruguayan anti-poverty program PANES), and Spain's Plan for Rural Employment (PER).

Public employment, rather than other types of public spending, is a particularly effective political tool because it can be targeted to specific individuals and easily withdrawn from them (especially if it is temporary). As stated by Robinson and Verdier (2013, p. 68), public jobs are "a credible, selective and reversible method of redistribution, which ties the continuation utility of a voter to the political success of a particular politician." Nevertheless, employment policies have received less attention from political economists than other types of government programs. Instead, the studies that document the electoral effects of government interventions focus on welfare programs - especially anti-poverty programs - and fiscal policies. Regarding the former, most studies focus on Latin American policies, such as the Uruguayan PANES or the Mexican PRONASOL (see, e.g., Manacorda et al. 2011; De La O 2012; Bruhn 1996; Diaz-Cayeros et al. 2008; and Zucco 2011). ${ }^{3}$

1 An undesired side effect of public employment in Italy is that it has generated some nepotism. Scoppa (2009) provides evidence of this fact as he finds that in Italy, children of public sector employees are more likely to have public jobs than children whose parents are not public employees. The author presents additional results that support the idea that such occupational persistence is explained by nepotism rather than by other factors, such as intergenerationally transmitted preferences.

2 In contrast to these studies, Mattos and França (2011) find that public employment fosters income concentration in Brazilian municipalities.

3 Outside Latin America, Labonne (2013) finds evidence that in the Philippines municipalities that benefited significantly from a conditional cash transfers program were more prone to support the incumbent government. 
Fiscal policies are the second type of intervention whose electoral impact has been examined broadly. Some studies focus on the effect of budget deficits on incumbents' reelection chances (Brender and Drazen 2008; Brender 2003). Others analyze the effects of the level and composition of public spending on electoral outcomes (see, e.g., Sakurai and Menezes-Filho 2008; Peltzman 1992; Levitt and Snyder 1997; Drazen and Eslava 2010 and Nazareno et al. 2006).

The aim of this paper is to evaluate whether the allocation of public jobs increases electoral support for the incumbent government, an issue that, to date, remains understudied. We do this by examining the Spanish Plan for Rural Employment (Plan de Empleo Rural, PER). The PER was introduced in the early 1980s in Andalusia and Extremadura (two southern regions in Spain) in order to soften the negative consequences of the regions' high unemployment rates. The program generates temporary employment targeted at agricultural workers, who suffer the most from seasonal unemployment. The policy also has granted additional rents to low-income households, but in terms of economic development, the affected regions still lag well behind the average regional per-capita GDP and unemployment rates. ${ }^{4}$

Ten years after the program was introduced, a report released by the Commission of Agriculture, Farming and Fisheries of the Spanish Congress raised concerns about the harmful consequences of the program and stated that "the system has fostered in Andalusia and Extremadura a culture of inactivity, which blocks any initiative of development and deactivates the willingness to work." 5

What could then explain the permanence of such unproductive spending? In Spain, the perception is widespread that the PER has merely served as a political instrument at the disposal of the Socialist Party (Partido Socialista Obrero Español, PSOE), which established the program initially and turned Extremadura and Andalusia into party strongholds. ${ }^{6}$ Thus, a strong reason for keeping the program in place could be that politicians see public employment

4 According to the National Statistics Institute (INE), in 2011 Andalusia and Extremadura's GDP per capita were $25 \%$ and $30 \%$, respectively, below the national average (and the two lowest in Spain); the unemployment rates for the same year were $40 \%$ and $15 \%$, respectively, above the national average.

5 Statement extracted from the report Dictamen aprobado por la Comisión de Agricultura, Ganadería y Pesca en relación con el informe elaborado por la ponencia especial para estudiar la reforma del actual sistema del Plan de Empleo Rural (PER) y el subsidio agrario. (154/000005), p. 21. Despite suggesting the need for reforms, the program has not undergone substantive changes since it was established.

6 The list of newspaper articles reporting this fact is extensive. This is just one of the many examples: "The PSOE sweeps to victory in the PER villages." ABC, 29/11/1993 http://hemeroteca.abc.es/nav/Navigate.exe/hemeroteca/madrid/abc/1993/11/29/052.html 
as a fruitful source of electoral rewards that compensates for the inefficient redistribution of income through jobs and, in turn, for the negative effect on economic growth. Further, the PER has often been cited as an example of clientelism: namely, the direct exchange of votes for access to public employment. ${ }^{7}$ According to Corzo Fernández (2002, p. 189), "the Plan for Rural Employment is a public policy directly identified with the captive vote, clientelism, caciquismo, and corruption." 8

As the name indicates, the PER was designed to target rural municipalities wherein agriculture is the main economic activity; in urban areas, the percentage of PER workers (i.e., policy beneficiaries) is significantly smaller. This is a key element in our identification strategy, which consists of applying a difference-in-differences matching estimator (Heckman et al. 1997, 1998; Abadie 2005) to a dataset of electoral outcomes over the 1979-1996 period. With a two-step approach, we obtain the average treatment effect on the treated group by first matching control and treated municipalities based on propensity scores and then using the corresponding weights to compute the differences in the outcomes for the treated and control groups over time.

The empirical analysis shows that the average treatment effect on the treated municipalities was a 3.8-percentage-point increase in the vote share of the Socialist Party in the general elections as well as a 1.3-percentage-point increase in the vote share of the Communist partyalthough the latter vanished over time. We do not find robust evidence of any effect on the electoral support for the main opposition party (the People's Party). In addition, we test for the presence of turnout buying in general elections, but we do not find any voter turnout effects.

The contribution of this paper is twofold. First, it contributes to the empirical literature on distributive politics. This strand of literature within the field of political economy has provided considerable evidence of the political motives behind public spending. The main determinants identified by this literature are partisan alignment (e.g., Arulampalam et al. 2009), the percentage of swing or core voters (e.g., Dixit and Londregan 1996; Lindbeck and Weibull 1987), ethnic favoritism (e.g., Burgess et al. 2015), and electoral cycles (e.g.,

7 See, for instance, Cazorla (1995), Hopkin (2001), and Hopkin and Mastropaolo (2001).

8 In the Spanish context, the term caciquismo is commonly used to refer to clientelism. 
Shi and Svensson 2006). ${ }^{9}$ Less quantitative evidence exists for the electoral returns to such expenditures, particularly for public employment interventions. Nevertheless, the results of this paper are consistent with the significant electoral returns found in two earlier studies. Folke et al. (2011) evaluate the impact of the introduction of civil service reforms in US states over the 1885-1995 period and show that when public jobs can be delivered with discretion, the probability of holding legislative control over the next four or eight years is higher. Calvo and Murillo (2004) find that in Argentina, the percentage of provincial public employees helped increase the percentage of congressional votes obtained by the Peronist Party, while it had no statistically significant effect on the vote share of the UCR-Alianza Party.

This paper makes a second contribution by exploring a case study that has received a great deal of attention from the Spanish press and some international scholars (see, e.g., Hopkin 2001), but for which formal quantitative evidence has yet to be provided. Despite the specific features of the case study, we think that the approach can be used to examine other programs of public employment (especially, those for which no clear rules on the allocation of jobs have been provided).

The paper proceeds as follows. In Section 2, we review the literature on bureaucratic effects on public policies and electoral outcomes. In Section 3, we present in detail the functioning of the Plan for Rural Employment. In Section 4, we describe the data used and the empirical strategy. In Section 5, we present the results, and in Section 6, we conclude.

\section{Bureaucrats, policies, and politics}

A distinctive feature of the public labor market is that the allocation of jobs is determined by bureaucrats and politicians or, rather, by their joint negotiations. Thus, bureaucrats can, to a certain extent, influence public sector wages and the amount of public money spent. ${ }^{10}$ William Niskanen was the first to develop a formal model of bureaucratic supply of public output (Niskanen 1967, 1971). Niskanen (2001) later modeled bureaucrats as maximizing

$9 \quad$ For an extensive review of the literature on distributive politics, see Golden and Min (2013).

10 The extent to which public employees can influence government spending is determined by their market power (Courant et al. 1979). Moreover, if public spending is the outcome of a bargaining process between politicians and bureaucrats (Breton and Wintrobe 1975), the politician's political prowess may also help to limit the government's budget (Dahlberg and Mörk 2006). 
their agency's discretionary budget. ${ }^{11}$

Although, in a Keynesian model, an oversupply of public employment may be helpful in times of economic crisis, many scholars have wondered why governments choose such an inefficient policy. One of the reasons identified by the political economy literature is the impact of public employment on electoral outcomes. That effect may explain in part why public employment increases opportunistically when elections are close (see, e.g., Katsimi 1998; Dahlberg and Mörk 2011).

As Buchanan (1977) noted, public employees are like any other person in that they cast their votes to further their own interests, that is, voting with the aim of expanding the size and scope of the government. They represent a relatively homogeneous group who can exert effective political pressure and support because they can organize at a lower cost. This explains, in part, why public sector employees turn out to vote at rates that exceed those of their private sector counterparts with otherwise similar characteristics (Corey and Garand 2002; Johnson and Libecap 1991; Bhatti and Hansen 2013). ${ }^{12}$

In the context of developing countries or weak democratic systems, the high participation rate of public employees is sometimes attributed to turnout buying. This is especially relevant in secret-ballot elections where politicians cannot monitor the vote perfectly, but they can observe "a range of other actions and behaviors that allow [them] to make good guesses" (Brusco et al. 2004, p. 68). In such a context, another possibility is that public jobs are exchanged directly for political support. The political machine created by the Christian Democratic party in Southern Italy is a well-known example of such a practice. ${ }^{13}$ The Italian and Spanish experiences have frequently been compared owing to their similarities (see Hopkin and Mastropaolo 2001): Public employment is targeted to low-income regions, and it has created important electoral strongholds for the parties that deliver jobs.

To the best of our knowledge, only two papers examine the effect of public employment on electoral support for political parties. The first is a study of the Argentinean case conducted by Calvo and Murillo (2004). The authors examine the returns to public employment for the

11 This behavior translates into a public sector whose budget is larger than is socially optimal. Chang and Turnbull (2002) find empirical support for this hypothesis using data on Taiwan.

12 Public employees are found to be not only more prone to electoral participation but also more sensitive to public reform proposals than private sector workers (Ratts $\varnothing$ and Sørensen 2004).

13 See Chubb $(1981,1982)$ for a comprehensive study of Italian patronage. 
two main parties in the country: the Peronist Party (PJ) and the Radical Civic Union (UCR). Theirs is the first study to examine simultaneously the demand side (voters' dependence on jobs) and the supply side (the political party's access to jobs) of patronage exchanges. Their analysis suggests that, because of institutional factors, the PJ enjoyed a clear advantage in having access to fiscal resources, which could be used to hire public employees. At the same time, the PJ's constituents depended greatly on public spending. The combination of these two factors translated into larger electoral returns for the PJ than for the UCR. The results of the study suggest that raising the percentage of public employees from $5 \%$ to $11 \%$ should deliver $6 \%$ more votes to the PJ, while the UCR's share of votes is unaffected.

The second study that examines the electoral rewards to patronage is that of Folke et al. (2011), who focus on the supply side of patronage and examine whether political parties in the United States used public jobs to increase the chances of their incumbents being reelected. The study tests whether the probability that a party maintains control of the state legislature over several elections was higher before civil service reforms were put in place in US states. Such reforms were introduced to reduce incumbents' capacity to use public employment to affect electoral outcomes (in other words, to limit the "spoils system"). According to their results, for a party that gained control of the state legislature in a certain year, the probability that the party would continue to hold such control in the next four elections was about 25 percentage points higher before the introduction of civil service reforms.

The literature mentioned in this section suggests that two relevant aspects of politics should be taken into account when examining the effects of public employment policies on electoral outcomes. The first one is the voter turnout rate, which is supposed to be positively correlated with the amount of public employment. The second is the effect on the support for different political parties. In the following sections, both aspects are examined in the context of the introduction of the Spanish Plan for Rural Employment. As explained in the next section, the types of public jobs offered by the PER are different from bureaucratic jobs, given that workers are not hired to serve the public administration. Nevertheless, the PER provides jobs funded by the central government, which creates a strong interdependence between the voters and the party in power. 


\section{Spain's Plan for Rural Employment}

\subsection{Institutional framework}

In 1982, the Socialist Party came to power in the Spanish Parliament for the first time in the history of this party. One of the first public programs the party implemented was the PER, which was in effect from January 1984. ${ }^{14}$ The PER was aimed at alleviating the effects of high seasonal unemployment in rural areas. Royal Decree 3237/83 determined that the only regions (so-called Autonomous Communities) that could access the program would be those where the unemployment rate among "seasonal agricultural workers" (trabajadores eventuales agrarios) was above the national average or where the number of such workers was proportionally larger than in other rural areas.

In Spain, regions are political and administrative divisions with fairly wide-ranging spending responsibilities that have been devolved by the central government from the 1980s onward. Seventeen Autonomous Communities have been identified with significant socioeconomic differences among them. The scope of the PER was limited at first to two regions (Andalusia and Extremadura), which were the only ones that fulfilled the statutory requirements: In 1983, the unemployment rate among the agricultural workers in Andalusia and Extremadura was $26 \%,{ }^{15}$ compared to $11 \%$ in the rest of Spain. The Plan for Rural Employment, financed mainly by funds from the National Employment Public Service, allowed municipalities to hire workers (mostly agricultural) to develop local public works (e.g., forest rehabilitation and construction of irrigation ditches). These jobs help agricultural workers to accrue the minimum number of working days needed to claim a special unemployment benefit (the agrarian subsidy), which is otherwise difficult to obtain. ${ }^{16}$ The PER remained unchanged until 1996, when the People's Party (PP) came to power and extended the program to the adjacent regions of Murcia, Castile-La Mancha and Castile-Leon. The program was then renamed PFEA (Pograma de Fomento del Empleo Agrario).

The PER was introduced to replace the Community Employment program (Empleo Co-

14 It was regulated initially by the Royal Decree 3237/1983 of 28 December and the Royal Decree 513/84 of 11 January 1984. The few amendments introduced afterwards are not relevant for this study.

15 In 1984, 1985, and 1986, this figure increased to $46 \%, 44 \%$, and $48 \%$, respectively, while it remained below $17 \%$ in the other Spanish regions.

16 As shown by Jofre-Monseny (2014), the agrarian subsidy has contributed to a reduction in the flows of people leaving rural municipalities in Andalusia and Extremadura. 
munitario), established in 1971 by the Franco regime. The Community Employment plan was designed to tackle the problem of unemployment but also, and most importantly, to keep social unrest under control. ${ }^{17}$ Initially, the distribution of jobs was decided by the civil governors according to the level of social tension. By the end of the 1970s, it was not only the central government (ruled at that time by the party Unión de Centro Democrático, UCD) ${ }^{18}$ distributing the Community Employment plan's funds but also, and especially, the main labor unions (Comisiones Obreras, CCOO, and Unión General de Trabajadores, UGT), which were accused of engaging in clientelist relations to recruit new members for the organization (González 1990). At that time, the PSOE was neither a consolidated nor well-structured political party as Hopkin and Mastropaolo (2001, p. 166) note: "the [socialist] party essentially consisted of small groups of ambitious young politicians in a handful of cities."

Municipalities comprise the lowest layer of government in Spain. ${ }^{19}$ They are represented by strong mayors elected under a proportional representation system every four years, coinciding with the general elections. The vast majority of municipalities are small (with fewer than 1,000 inhabitants), and they often require resources from upper-level governments, such as the central and regional governments or the provincial governments. The latter is an upperlocal layer of government that is not elected directly but is composed of council members chosen in local elections. ${ }^{20}$ The main task of provincial governments is to assist municipalities technically and economically (especially the smallest ones). The implementation of the PER requires coordination among these governments. The central government, through the National Employment Public Service, distributes the PER budget among its provincial delegations that act as regulatory bodies. Such commissions evaluate and approve or dismiss the reports sent by the city councils, which identify the types of projects to be funded, the number of workers required, and the percentage of agricultural workers to be hired. The main criterion for allocating projects is the unemployment rate, and the main requirement to be fulfilled by the projects is that a substantial percentage (in many cases up to $75 \%$ ) of the workers hired

17 In the 1960s, a mass exodus of agrarian workers to industrial areas took place. This migration reduced the size of the agricultural labor force and raised salaries. Big landowners were concerned about that eventuality and requested state intervention.

18 The UCD was a center-right party that played a major role during the Spanish transition to democracy. The UCD was the first party in government after the Francoist dictatorship, and the party held power between 1977 and 1982, after which it was replaced by the Socialist Party.

19 In total, Spain has approximately 8,000 municipalities.

20 Spain has 50 provinces in total; Andalusia and Extremadura have eight and two, respectively. 
must be currently unemployed seasonal agricultural workers. Once the provincial delegations approve the projects and their financing, the city council selects the workers. ${ }^{21}$ Table 1 shows some basic facts about the PER. First, the number of PER contracts signed each year grew substantially until 1987. Part of this increase is explained by the increasing participation of women in agriculture, which happened especially during the early years of the program. The reduction in the number of jobs after 1987 can be attributed partly to more stringent monitoring, the fallout from several fraud cases that surfaced in the late 1980s. Second, investment per capita in real terms increased substantially during the 1984-1993 period. This is shown in the last column of Table 1, where the figures are in real pesetas (the Spanish currency at the time) per capita. The fact that the number of contracts did not follow the same trend in the later years has two plausible explanations: PER projects may have become more costly owing to an increase in wages or materials costs, or the number of working hours paid for by the PER may have grown. ${ }^{22}$

[Table 1 about here.]

Although very little information on the local distribution of PER beneficiaries exists, the available information suggests that nearly all municipalities in the affected regions have PER workers. What differs among municipalities is the number of such workers. ${ }^{23}$ In Section 4 , we examine the determinants of the distribution of PER beneficiaries.

\subsection{Political economy considerations}

A common public opinion in Spain is that the PER acts as a breeding ground for clientelism. ${ }^{24}$ This is because the beneficiaries are low-income workers and the selection of workers is largely

21 The central government provides municipalities with most of the money they need to provide the jobs. In addition, the regional government dispenses a smaller fraction of the funds required that covers the cost of materials and equipment. Whenever all of these amounts are not sufficient, the local government defrays a portion of the cost.

22 An increase in PER hours happens when weather conditions are particularly bad, production falls, and so do the number of hours worked in the agricultural sector. In this context, agricultural workers need to be employed more hours on PER projects to have access to unemployment benefits.

Unfortunately, a systematic collection of data on the geographic distribution of PER recipients at the municipal level did not take place during the early years of the program. For the present study, provincial and regional governments have provided the following information: data on funds and workers in the province of Granada (Andalusia) for 1998-2007, data on funds and workers in the province of Badajoz (Extremadura) for 2008, and data on the distribution of funds in Andalusia for 2008-2010. In Granada and Badajoz, for the years when data are available, $99 \%$ of the municipalities had PER workers.

24 See, for instance, the following media reports: 
discretionary. ${ }^{25}$ Moreover, thanks to the PER, the central government consolidated its influence in rural areas through the city councils, which manage the program and became the main source of employment in most municipalities, especially in the small ones (Martín 2007).

A controversial issue related to the PER is fraud. A claim often heard is that mayors sign fraudulent agrarian cards stating excessive numbers of hours worked on PER projects. Some argue that the PER is responsible for large percentages of unfinished public works and for inflated claims about the number of unemployed people in Andalusia and Extremadura. For instance, Cazorla (1995) reports that in the village of Badolatosa, during a certain year the number of PER beneficiaries was greater than the total working-age population (both employed and unemployed). Another example can be found in the Andalusian municipality of Pinos Puente where the number of subsidized workers increased from 900 in 1984 to 4,500 in 1987 (i.e., from $7 \%$ to $33 \%$ of the total population). ${ }^{26}$ Although this could suggest that an "exchange relationship" arises at the local level (between mayors and citizens who meet directly), the PER is a policy that citizens in the affected regions can clearly identify with the central government. This is because the PER is a national policy whose continuation depends on the willingness of the central government, and voters are aware of this fact. According to Corzo Fernández (2002, p. 336) "the clientelist relation is not established with the closest level of power but, if it exists it is with the one who takes the most relevant decisions."

It is outside the scope of this paper to provide evidence for the rewards for clientelism. We believe that this is a complex endeavor that cannot be pursued with the data currently available (electoral outcomes aggregated at the municipality level). As discussed in Kitschelt and Wilkinson (2007), the difficulty lies in providing a clear identification of the patronage relationship and the subjectivity in assessing the real motivations behind the exchange of votes. In other words, proving that a quid-pro-quo arrangement exists is a challenging matter

"Andalusian economists ask to eliminate the PER because it fosters fraud and 'clientelism' ". El Mundo, 22/08/2012 http://www.elmundo.es/elmundo/2012/08/22/andalucia/1345664993.html

"PER recipients constitute a group who is mainly thankful to the government. The subsidized countryside votes for those who rule. This is the modern form of clientelism." ABC 29/11/1993 http://hemeroteca.abc.es/nav/Navigate.exe/hemeroteca/madrid/abc/1993/11/29/047.html

25 Poor citizens often are regarded as more susceptible to clientelism provided that the utility they obtain from the private rewards exceeds the disutility of voting contrary to their ideological preferences (Stokes 2005).

26 In this particular case, a fraud investigation started in 1990, and the mayor of Pinos Puente was sentenced to 18 months' imprisonment for having approved 200,000 working hours for 4,000 laborers. http://elpais.com/diario/1996/06/08/espana/834184817_850215.html 
that requires more precise information, such as individual-level survey data (as in Calvo and Murillo 2004 or Brusco et al. 2004).

Regardless of these limitations, our database of election results allows us to assess the aggregate change in support for the incumbent central government after the introduction of the policy. Two motivations predict higher electoral support for the Socialist Party. On the one hand, unemployed people who benefited directly from PER jobs might be grateful to the party that introduced the policy and, thus, they might vote for the PSOE. On the other hand, citizens who did not receive a PER job but benefited indirectly could also support the program and, in turn, the Socialist Party. This would be the case for members of a household with a PER worker or other citizens who believe that the PER has a positive impact on the municipality as the program prevents depopulation of rural towns. Thus, although for the 1984-1993 period, on average, only 2.5\% of the population in Andalusia and Extremadura had a PER job, the number of people affected indirectly by this policy was potentially much higher.

There were two other parties whose electoral support could have been altered due to the introduction of the program: the Communist Party (initially Partido Comunista de España, PCE, and after 1986 comparable to Izquierda Unida, IU), and the People's Party (the main opposition party). The change in the support for the PCE is, a priori, ambiguous. As noted previously, the main unions (which where closely linked to the Communist Party) were accused of attracting affiliates through the discretionary allocation of funds from the Community Employment program. If this were the case, then the introduction of the PER, which left the unions with no control over the program's funds, could have translated into lower vote shares for the Communist Party. In parallel, the UGT union (contrary to the actions of the CCOO) supported the approval of the program and this endorsement could have led to an increase in support for the PCE. The effect on the electoral support for the People's Party (PP) is also unclear. Although the PP did not oppose the introduction of the PER in 1984, the party strongly criticized the program later on, especially when the fraud cases appeared. ${ }^{27}$ If PER beneficiaries feared that the program would disappear - or lose its

27 In 1994, the PP proposed an amendment to the PER advocating for increased involvement by the private sector and better support for unemployed individuals through occupational training. During a debate in the Spanish Congress, a PP representative stated that "our party has never questioned social care services, but we do question the current system which does not contribute at all to the creation of wealth. The PER has nothing to do with employment or ruralness." ABC newspaper 23/02/1994. 
discretion - once the People's Party is in power, they would have had an incentive not to support this party.

\section{Empirical approach and data}

\subsection{Identification strategy and estimation}

In this study, we are interested in finding the impact of the introduction of the Plan for Rural Employment on the electoral support for the Socialist Party in the affected municipalities (i.e., the average treatment effect on the treated, ATT). As it is not possible to observe electoral outcomes at the same point in time in the treatment municipalities with and without the existence of the PER, we turn to non-experimental methods. In particular, we use a combination of difference-in-differences (DiD) and matching methodologies. This allows us to relax the strong assumption of parallel trends on which the conventional DiD is based. Further, to account for the fact that it is essentially rural municipalities in Andalusia and Extremadura that benefit from the PER, we restrict our sample to this type of municipality in the treatment and control regions. Below, we discuss the econometric strategy, a key part of which is the choice of the control group and the variables used to match the treatment and control municipalities.

\section{Treatment and control groups}

As explained in Section 3, although all municipalities in Andalusia and Extremadura can benefit from the PER, the program targets mostly rural towns. Therefore, the treatment group is limited to this type of municipality. Provided that none of the decrees that regulate the PER specifies which sort of municipality should be regarded as rural, we use an objective measure set by the Spanish Ministry of Agriculture that defines rural towns as municipalities in Andalusia and Extremadura that have fewer than 5,000 inhabitants and a population density lower than 100 inhabitants $/ \mathrm{km}^{2} .{ }^{28}$ Municipalities that do not fulfill this requirement

http://hemeroteca.abc.es/nav/Navigate.exe/hemeroteca/madrid/abc/1994/02/23/073.html

28 Alternative definitions of rural areas are those given by Eurostat and the Organization for Economic Cooperation and Development (OECD) that consider rural municipalities are those with fewer than 100 persons $/ \mathrm{km}^{2}$ or 150 persons $/ \mathrm{km}^{2}$, respectively. We believe, however, that the most appropriate definition is the one given by the Ministry of Agriculture in the Ley de Desarrollo Sostenible del Medio Rural (Law for the Sustainable Development of Rural Areas, Law 45/2007). 
are excluded from the main analysis and are used in the robustness section of this paper as placebo municipalities.

As we discuss in Section 5, the econometric analysis shows that rural towns in Andalusia and Extremadura have a significantly larger percentage of PER beneficiaries than urban municipalities. We also show that municipalities with higher unemployment rates have a larger concentration of beneficiaries. Nevertheless, we believe that unemployment rates are a less suitable indicator as it is not possible to set a clear and objective threshold above which a municipality can be considered a PER beneficiary. ${ }^{29}$ Moreover, the unemployment rate in rural towns is, in most cases, higher than that of the average municipality. Therefore, we think that being a rural town is a good indicator that the municipality benefits from the PER.

Regarding the control group, it includes only rural towns in the adjacent regions of CastileLa Mancha, Castile-Leon, and Murcia (see the map in Figure 1 for these regions' geographic locations). The control regions were chosen to reduce to the greatest possible extent the disparities between the treatment and control groups. We believe that Castile-La Mancha, Castile-Leon, and Murcia constitute a good control group given that the PER was extended to these regions in 1996 (the last year included in our study). This extension is explained by the increasing unemployment problems faced by the agricultural sector in those three regions (a situation similar to that of Andalusia and Extremadura). Further, on the socioeconomic side, before the PER was instituted, these five regions were, on average, rural regions with low population density, a per-capita GDP lower than the average, and a large agricultural sector with high seasonal unemployment rates. If the control group were all the Spanish regions excluding Andalusia and Extremadura, the differences in the economic structure would be larger (see Table 2). For instance, the Basque Country and Catalonia are more industrialized regions with lower agricultural production and are less rural (if proxied by their population density). Moreover, on the political side, regionalist parties have a strong presence in these regions, which makes them less comparable to the treatment group, thus making them less appropriate as control groups. ${ }^{30}$

29 For instance, the use of the average unemployment rate to distinguish between municipalities with high and low unemployment is not suitable given that the rate varies greatly over the years.

30 From 1982 until 1995 (the period under study), the regional governments of the control regions, with the exception of Castile-Leon from 1987, were governed by the Socialist Party. 
[Figure 1 about here.]

[Table 2 about here.]

\section{Econometric strategy}

Despite the rigorous choice of the control group and the restriction of the sample to rural towns in the treatment and control groups, the treated and untreated municipalities are in different regions. This means that it is likely that the treatment and control municipalities differ in observed characteristics that affect the dynamics of the outcome variables in the pre-treatment period. ${ }^{31}$ Consequently, the assumption of parallel trends in the pre-treatment years required by a conventional $\mathrm{DiD}$ analysis is implausible. In such instances, scholars (see, e.g., Abadie 2005) suggest the use of a two-step strategy that combines a differencein-differences approach with propensity score matching. The procedure allows the treatment effect to vary across municipalities and has its origin in Heckman et al. $(1997,1998) .{ }^{32}$ With this strategy, we can create a control group in which all treated municipalities find a similar counterpart.

In the first stage of the empirical analysis, municipalities in the control group are matched to those in the treatment group using a propensity score, $P\left(X_{i}\right)=\operatorname{Prob}\left(\operatorname{PER} R_{i}=1 \mid X_{i}\right)$, based on a set of characteristics $\left(X_{i}\right)$ measured during the pre-treatment period. These characteristics are socioeconomic factors that are thought to be related to the treatment and outcomes (see the exact variables and further discussion in the next section).

In the second stage, we estimate the treatment effect $(\tau)$ using a difference-in-differences approach as follows:

$$
Y_{i t}=\alpha_{i}+\mu_{t}+\tau P E R_{i t}+\lambda^{\prime} X_{i t}+\varepsilon_{i t}
$$

where $Y_{i t}$ denotes the outcome of interest (i.e., election outcomes) for municipality $i$ at electoral term $t ; \alpha_{i}$ and $\mu_{t}$ are municipality and time effects, to control for municipality-specific omitted variables and time trends, respectively; $X_{i t}$ is a vector of the time-varying covariates;

31 As we show in the next section, a comparison of the means of the observable variables in the treatment and control municipalities reveals significant differences in terms of population size, unemployment, education, population density, and population growth (variables that may influence our outcomes of interest).

32 Abadie (2005) proposes a semiparametric difference-in-differences estimator similar to that of Heckman et al. $(1997,1998)$ but with a different weighting scheme. 
$\varepsilon_{i t}$ is the time-varying error term (assumed to be independently distributed); $P E R_{i t}$ is a binary variable equal to one if the region is affected by the program at election $t$ (thus, before 1984, this indicator is fixed at zero). The key estimate is $\tau$, the treatment effect on the treated.

In the second stage, we use the weights obtained through propensity score matching in the first stage to compare the differences between the pre- and post-treatment electoral outcomes for the treated municipalities relative to the weighted averages of the pre- and post-treatment electoral outcomes in the control municipalities. Therefore, we obtain a DiD estimator that is conditional on some observable variables, and the average treatment effect on the treated is estimated as:

$$
\hat{\tau}_{A T T}=\sum_{i \in\{P E R=1\}}\left[\left(Y_{i 1}-Y_{i 0}\right)-\sum_{j \in P E R=0} W_{i j}\left(Y_{j 1}-Y_{j 0}\right)\right] w_{i}
$$

where $Y_{i 1}$ and $Y_{i 0}$ are the outcomes of the treated municipality $i$ in the post- and pretreatment periods, respectively, and are similar for municipalities $j$ in the control group; $W_{i j}$ are the weights obtained in the first stage using kernel regression; and $w_{i}$ reweights the distribution of the electoral outcomes for the treated municipalities. ${ }^{33}$

Last, the error term in our model may suffer from a serial correlation problem. Political preferences in a municipality are quite persistent over time: Many municipalities have a historical record of repeatedly voting en masse for a specific party. Therefore, to provide consistent estimates, the errors are clustered at the municipality level.

\subsection{Data and variables}

\section{Sample}

The database used to examine the potential effect of the PER on election outcomes consists of electoral results (vote share of the Socialist and other parties) and voter turnout in the general elections. The data are aggregated at the municipality level as there are no survey data to examine the individual behavior of the beneficiaries and non-beneficiaries of the PER. Nevertheless, the PER affected not only PER workers but also their families and other people

33 Recall that $\hat{\tau}_{M}=\sum_{i \in\{P E R=1\}}\left[Y_{i}-\sum_{j \epsilon\{P E R=0\}} W_{i j} Y_{j}\right] w_{i}$ is the matching estimator of the average effect of the treatment on the treated municipalities. In other words, the DiD estimates are weighted by the likelihood of being treated. 
living in rural towns. Thus, we believe the level of aggregation, although imperfect, is not problematic.

The data cover the elections held between 1979 and 1996, and the information was collected from the Ministry of Home Affairs. ${ }^{34}$ Electoral data are available since 1977, the year of the first democratic election after Franco's dictatorship. The 1977 general election, however, is excluded from our analysis as some crucial data are unavailable for that year. Therefore, the period under study starts in 1979, the year of the second democratic election. The last election included in the study is the general election of 1996 because after the electoral victory of the People's Party that year the PER was extended to Castile-La Mancha, Castile-Leon, and Murcia (the control regions). Thus, the elections taken into consideration are those held in 1979, 1982, 1986, 1989, 1993, and 1996.

Not all municipalities in Andalusia and Extremadura are included in this study because the only relevant units that should be considered treated units are rural municipalities. Following the definition of rural towns (fewer than 5,000 inhabitants and population density below 100 persons $/ \mathrm{km}^{2}$ ), the sample excludes around $30 \%$ of the municipalities (approximately 330 out of 1,100$)$ in Andalusia and Extremadura.

A closer look at the most reliable information we have on the distribution of PER municipalities (i.e., data on the province of Granada for the 1998-2007 period) reveals significant disparities in the number of PER beneficiaries as a percentage of the working-age population. The average percentage of beneficiaries totals $10 \%$ (with a standard deviation of 8.2 ). This figure is mostly driven by small municipalities (with fewer than 5,000 inhabitants) that have, on average, $11.6 \%$ of beneficiaries while big municipalities with more than 50,000 inhabitants have, on average, $4 \%$ of beneficiaries. The two biggest municipalities in the province (Granada and Motril) are included in this last group. We also observe that the set of municipalities with the largest percentage of beneficiaries remains constant over time (e.g., the towns of Alamedilla, Cacin, and Alicun de Ortega are in the top ten for most of the years for which we have data). This is consistent with the fact that the program helped rural towns maintain their agrarian activity, and, therefore, the incidence of the PER remained fairly persistent over time.

To further examine the data we have on Granada over nine years, we use a k-means

34 The data are publicly available at http://www.infoelectoral.mir.es/. 
clustering method. This allows us to divide the municipalities into two clusters where one has a higher percentage of PER beneficiaries and the other a lower percentage. The variables used for the analysis are the percentage of PER beneficiaries, population size, population density, and unemployment rate. The first cluster includes municipalities with a high percentage of beneficiaries (on average, about 10\%), small population size and density (on average, 4,000 and 169 , respectively), and a high unemployment rate (37\% on average). In contrast, the second cluster consists of municipalities with, on average, $0.2 \%$ of program beneficiaries, as well as a

high population density $\left(2,728\right.$ persons $\left./ \mathrm{km}^{2}\right)$, large population size $(240,166$ inhabitants), and lower unemployment rate $(22 \%)$. The cluster analysis reinforces our hypothesis that being a rural town is a good variable by which to divide municipalities into those where there is a small concentration of beneficiaries and those that are largely affected by the PER.

To sum up, the final sample, which is restricted to observations inside the range of common support, contains information for 3,000 rural towns in Andalusia, Extremadura, Castile-La Mancha, Castile-Leon, and Murcia, 25\% of which are treated units. The remaining $75 \%$ are used as the control municipalities.

\section{Covariates used for the matching and other controls}

One of the main issues in matching methods is the variables to include in the propensity score. The selection of covariates should be such that the outcome variables are independent of the treatment conditional on the propensity score. To fulfill the conditional independence assumption, we follow previous literature (Heckman et al. 1997) and restrict the set of variables to only those that affect the treatment and outcomes simultaneously. The PER is targeted at rural towns with high unemployment. These are towns with a small population size and low (or even negative) population growth. Given that agricultural workers are, on average, educated to a lesser extent, PER towns usually have lower education levels. We provide evidence of all these claims in the next section.

Regarding the factors that may affect electoral outcomes, in Spain (as in other countries), voting patterns differ between rural and urban areas, as well as across social groups (Hopkin 2001). The vote share of the PSOE in Spain at the beginning of the 1980s was, on average, significantly high among students and was lower for agricultural workers than for white collar employees and skilled workers (Boix 1998). Moreover, between 1982 and 1992, the PSOE's electoral support declined among young people and increased among retirees. 
Based on what we know about the factors that may influence electoral outcomes and the concentration of PER beneficiaries, the municipal-level covariates that we use to obtain propensity scores are unemployment rate, population size, education level (measured as the percentage of population over 16 who were enrolled in an education program during the census year), population density, and population growth. The matching procedure ought to be undertaken with values of these variables before the PER was introduced in 1984, so we rely on information from the 1981 population census conducted by the National Statistics Office. The set of covariates chosen is limited by the lack of data at the local level, which does not allow us to include the percentage of workers in different economic activities. However, we have information on the percentage of retired workers, which we use as a control variable in all regressions. We do not use this regressor to compute the propensity score because, although it may affect the outcome variable, it does not influence the distribution of PER workers. ${ }^{35}$

\section{Results}

\subsection{The determinants of the geographic distribution of PER beneficiaries}

The crucial aspect of our econometric strategy is to place a higher weight on observations in the sample with a higher probability of being treated so that the treatment effect is not homogeneous across municipalities. In the previous sections, we argued that rural towns in Andalusia and Extremadura have, on average, more PER beneficiaries than urban municipalities. Further, PER jobs are distributed by provincial commissions that take into account unemployment levels. To provide empirical evidence for these facts, we use the available data on the geographic distribution of PER beneficiaries in Granada over the years 1998-2007. We regress a set of covariates on a dependent variable that is the percentage of PER workers in a municipality. The explanatory variables used are unemployment rates (Unemployment), a dummy equal to one if the municipality has fewer than 5,000 inhabitants and its population density is below 100 persons $/ \mathrm{km}^{2}$ (Rural), Population growth, a binary variable equal to one

35 Recent studies (see, e.g., Austin 2011) suggest computing propensity scores using covariates which may be related to the outcome but not to the treatment. In our study, taking into account the percentage of retired people in the propensity score does not affect the findings. These results are available upon request. 
if a municipality's unemployment rate is above the average (High unemployment), a binary variable equal to one if the units of temporary wage labor per capita in the agricultural sector are above the average $(\text { Agrarian })^{36}$, two indicators of the education level of the municipalities (the percentage of people with Secondary education and the percentage of people with Tertiary education), and two political variables (a binary variable, Political alignment, that indicates whether a municipality's mayor is a member of the central government's ruling party, and a binary variable, Socialist mayor, that equals one if the mayor is affiliated with the PSOE).

Table 3 shows the estimates of the ordinary least squares (OLS) regressions with year dummies and standard errors clustered at the municipality level. In all specifications, the unemployment rate has a positive and statistically significant effect: A one percentage-point increase in the unemployment rate is associated with a $22 \%$ higher percentage of PER beneficiaries. In contrast, population growth is negatively correlated with the percentage of PER beneficiaries. The variable Agrarian is statistically insignificant in all regressions where it is included. This variable is used as a proxy for the agrarian activity of a municipality, which should be positively associated with the share of PER workers. Column 3 in Table 3 also reveals that, controlling for the unemployment level, among other things, rural towns have a 1.6 percentage points higher percentage of PER workers. In column 4, we add municipality fixed effects. Although the coefficient associated with Rural is still positive, it is no longer statistically significant. This is explained by the little variation that this variable (and the variable Agrarian) has over time. Therefore, the preferred specifications are those that do not include municipality fixed effects. The political variables included in columns 1 to 6 are statistically insignificant, which means that there is no evidence of partisan bias in the allocation of PER jobs from provincial commissions to municipalities. Last, the variables related to education have the expected negative sign as people with higher levels of education are less likely to work in the agrarian sector and, in turn, be PER beneficiaries.

[Table 3 about here.]

36 The units of temporary wage labor are obtained from the Agrarian Census published by the National Institute of Statistics. 


\subsection{First stage: choice of control municipalities}

In the first stage of our empirical strategy, we use propensity score matching to select a group of control municipalities. We estimate a probit model in which the dependent variable is equal to one if the town is in Andalusia or Extremadura (and zero otherwise) and the explanatory variables are the following: population size, education level, population density, and population growth. The matching is performed during the pre-treatment period using a cross-section regression that restricts the sample to the term before the PER was introduced. The propensity score obtained is then used to match the control and treated municipalities using kernel matching. In Table 4, we show the probit estimates.

[Table 4 about here.]

To ensure the propensity score has a similar distribution within blocks across the treatment and control groups, we check the balance of the specific covariates used to perform the matching by computing standardized differences (Rosenbaum and Rubin 1984). The results are presented in Table 5. The figures reveal that kernel matching helped to reduce considerably the differences between the treatment and control groups: In the unmatched sample, the standardized differences are well above $10 \%$ for all covariates but one; in the matched sample, such differences are eliminated in all covariates. ${ }^{37}$ Last, in Figure 2 we present the distribution of the propensity score across the treatment and control groups to show the level of overlap.

[Table 5 about here.]

[Figure 2 about here.]

\subsection{Political consequences of the introduction of the PER}

\section{Program effects on the support for the Socialist Party}

We start by reporting the ATT of the PER on the main variable of interest, namely, the Socialist Party's vote share in the general elections. Table 6 reports the ATT as expressed in

37 According to some studies, the maximum standardized difference that should be accepted ranges from $10 \%$ to $25 \%$ (Austin 2009; Stuart et al. 2013). 
Equation 1. As a baseline, in columns 1 and 2 we show the estimates of a classic differencein-differences approach (i.e., without matching the treated and control municipalities). As already discussed in the previous section, these results are likely to be biased; thus, in columns 3 and 4 we present estimates that correspond to the treatment effect expressed in Equation 2. The regression in the first column does not include control variables (only time and municipality fixed effects), while columns 2 to 4 include additional controls (population growth, the percentage of retired workers, an indicator of education, population size, unemployment rate, and population density). The explanatory variable labeled PER is the treatment variable, which is a dummy that equals one if the observation corresponds to a municipality in Andalusia and Extremadura after 1984 and zero otherwise. The DiD estimate in column 1 points to a statistically significant increase in support for the Socialist Party in the general elections of about 4.1 percentage points. This slightly overestimates the true ATT as shown in column 3, where the coefficient is 0.039 (0.2 points lower than the DiD estimates). As robustness, in column 4 we add five region-specific time trends. ${ }^{38}$ In this case, the coefficient of 0.038 indicates that the support for the Socialist Party in rural towns in Andalusia and Extremadura after 1984 grew by 3.8 percentage points more than in rural municipalities in the control regions. Because in the treated municipalities the average socialist vote share before the program was established was $45 \%$, the average treatment effect on the treated municipalities represents a $8.4 \%$ increase. This is an economically significant effect.

[Table 6 about here.]

\section{Program effects on voter turnout}

The increase in support for the Socialist Party could be explained partly by lower abstention rates among PSOE voters given that abstention in Spain tends to be higher for left-wing voters (including PSOE supporters) than for right-wing ones. ${ }^{39}$ Moreover, in line with the studies on clientelism, under a secret-ballot system, clientelism is more likely to increase turnout

38 An F-test rejects the hypothesis that the regional trends are jointly equal to zero.

39 A clear example is the Spanish general election of 2004 when there was a substantial increase in voter turnout of seven percentage points, which gave the PSOE its victory. The main opposition party, the People's Party, had a major loss of votes in percentage terms but not in absolute number of votes, which means that the mobilization of voters did not favor the PP (see Boso et al. 2005). Furthermore, in a quantitative analysis of the Spanish case, Rowe et al. (2014) find that a one-point increase in voter turnout raises the vote share of the Socialist Party by 0.5 points in the short run and by 0.9 points in the long run. 
than to buy votes (see, e.g., Nichter 2008). To examine this issue further, we run additional regressions using the voter turnout in general elections as a dependent variable. The outcomes are presented in Table 7 . The estimates in columns 1 and 3 show an increase in the voter turnout in general elections after the PER was introduced. Nevertheless, the direction of the effect changes once we include regional trends (columns 2 and 4). According to the F-test of joint significance of the regional trends, these effects are relevant and ought to be included in the regressions. When we apply a DiD approach combined with propensity score matching (column 4), the significance of the coefficient disappears. Thus, we can discard the hypothesis of turnout buying in general elections. The result is not surprising: Before 1984 there were already high levels of electoral participation.

[Table 7 about here.]

\section{Additional results}

As discussed in Section 2, the support for other relevant parties besides the PSOE could have also been altered by the introduction of the policy. In Table 8, we evaluate this hypothesis by estimating the effects of the PER on the vote share of the People's Party (column 1 and 2) and the Communist Party (column 3 and 4) in general elections. The regressions presented in Table 8 include control variables, as well as time and municipality fixed effects and regional trends. Although the results in column 1 suggest a sharp decrease in the PP vote share, this effect is no longer statistically significant once we control for regional trends (column 2). Therefore, although there is suggestive evidence that the PER negatively affected the People's Party, the results are not robust to the use of different specifications. The Communist Party, in contrast, benefited electorally as the PER increased support for this party by 1.3 percentage points, which for the average treated municipality would represent a $21 \%$ increase.

[Table 8 about here.]

Another relevant aspect to evaluate is whether the effects of the PER on support for the PSOE and the PCE are "program introduction effects" that disappeared over the years. To examine this idea, we include time dummies for the post-treatment elections interacted with the treatment variable (PER) and we take the first election after the introduction of the PER (in 1986) as the point of reference. The estimates are presented in Table 9. They show that the effect on the support for the Socialist Party is statistically significant in the first general 
election after 1984, did not increase further in the following elections, and decreased only 12 years later (in the 1996 election). Although the impact on the support for the Communist Party was initially large (even larger than for the PSOE), the impact decreased significantly over time.

[Table 9 about here.]

\subsection{Robustness tests}

To check the robustness of the previous findings, we perform several additional tests. An additional check to test the validity of the results consists of performing a falsification test in which we use a fake treatment group. This strategy involves excluding rural towns in Andalusia and Extremadura from the analysis and instead using urban municipalities as the treated units. This set of municipalities is matched to urban municipalities in Castile-La Mancha, Castile-Leon, and Murcia. In this case, we expect to find no statistically significant effect of the program on electoral outcomes. The estimates presented in Table 10 confirm these expectations: All coefficients are statistically insignificant. Therefore, we are confident that the rise in the vote share of the PSOE and the PCE observed in Andalusia and Extremadura is driven to a large extent by the Plan for Rural Employment.

[Table 10 about here.]

We also explore the possibility that the change in support for the main political parties is due to a change in the electorate caused by immigration from neighboring regions. If immigrants from Castile-Leon, Castile-La Mancha, and Murcia have different political preferences, this could explain the shift in votes. Although we do not have detailed data to test whether the composition of the electorate changed, there is suggestive evidence that this was not significantly affected by the PER. First, we estimate Equation 2 using the electoral census as the dependent variable. The results are reported in columns 1 and 2 in Table 11, and they reveal that even if the PER attracted workers from neighboring regions, the number of people registered as voters did not increase. Moreover, Jofre-Monseny (2014) provides evidence that the largest inflows of people migrating to Andalusia and Extremadura during the 1980s were from non-border regions. The author suggests that such inflows may be returned migration

(i.e., people from Andalusia and Extremadura who migrated to Catalonia, Madrid, and the 
Basque Country between the late 1950s and early 1970s); thus, the changes in the electoral preferences should be quite small.

[Table 11 about here.]

Finally, we examine the alternative explanation that it was not the PER but rather the decentralization process started in the early 1980s (before to the introduction of the PER) in Andalusia and Extremadura that affected the level of support for the Socialist Party in these regions. The Spanish Constitution approved in 1978 established the right of autonomy for the regions, which formed the basis for the current system of Autonomous Regions in Spain. Andalusia and Extremadura approved their Statute of Autonomy in 1981 and 1983, respectively, and this was followed by the decentralization of power from the central to regional governments, coupled with large transfers of funds to compensate for the costs. At the time of the approval of Andalusia and Extremadura's Statutes (and throughout the rest of the period in the sample), their regional governments were aligned with the central government, which could have led to certain biases in the allocation of transfers. ${ }^{40}$ If these funds were used, for example, to build new schools or hospitals especially in rural areas, voters could have further incentive to reward the PSOE. The decentralization process, however, should not have affected the electoral outcomes in Extremadura as the devolution of power in the health and education sectors took place in 2001 and 1999, respectively (CEOE 2011). In Andalusia, the devolution of power in these two sectors occurred in 1982 (education) and in 1999 (health). Thus, we consider only the decentralization of education in Andalusia as a potential confounder of the results. To test this possibility, we run additional regressions that include the number of education centers per 1,000 inhabitants as a control variable. ${ }^{41}$ The findings, presented in Table 12, show that the sign, significance, and magnitude of the coefficients associated with the treatment variable remain unchanged and therefore confirm the robustness of the results. Moreover, the number of education centers does not seem to have any statistically significant effect on electoral outcomes.

\section{[Table 12 about here.]}

\footnotetext{
40 Arulampalam et al. (2009) and Solé-Ollé and Sorribas-Navarro (2008) provide empirical evidence for such partisan bias for India and Spain, respectively.

41 The data are obtained from the establishments census.
} 


\section{Conclusion}

This article examines the electoral rewards to public employment using as a case study the Spanish Plan for Rural Employment (PER). This program provides temporary public jobs to agricultural workers in order to mitigate the negative consequences of high seasonal unemployment in the agricultural sector. The policy has been highly controversial since it was established in 1984: There is a widespread perception that the program was more beneficial politically than economically. In this sense, it is often argued that it was thanks to the PER that the Socialist Party not only was able to increase its support base but also created its two main strongholds in the regions where the program was introduced (Andalusia and Extremadura). However, until now, there has been no formal attempt to empirically test the electoral consequences of the PER.

We evaluate voters' responsiveness to this employment policy using municipal-level data over the 1979-1996 period and through employing a difference-in-differences matching estimator. The key aspect of the identification strategy is that the PER was designed to target rural towns, where agriculture is the main economic activity and unemployment rates are high. As the program was not implemented nationwide but limited to only two Spanish regions, we can match affected municipalities in the treatment group (Andalusia and Extremadura) with similar ones in a control group formed by adjacent regions with similar socioeconomic features.

Our results confirm the hypothesis that the incumbent government that introduced the program (the Socialist Party) was electorally rewarded. In municipalities affected by the program, we find a large increase of $8.4 \%$ in the socialist vote share in the general elections. This effect was persistent over the years, and it only started decreasing 12 years after the program was introduced. Moreover, we do not find any evidence of turnout buying given that electoral participation in the treated municipalities did not increase. Finally, the effect on the support for the Communist Party (which was also in favor of the PER) was initially positive and large but decreased rapidly over the years.

\section{Acknowledgements}

This paper benefited from the financial support of ECO2009-12680/ECON (the Spanish Ministry of Education and Science) and project 2009 SGR 102 (Generalitat de Catalunya). I 
thank Christina Gathmann, Albert Solé-Ollé, Pilar Sorribas-Navarro, two anonymous referees, and the editor of this journal for very useful suggestions and help. I am also grateful to Jordi Jofre-Monseny, the regional government of Andalusia, the provincial government of Granada, and the provincial delegation of the SEPE in Badajoz, for providing relevant data for this study. Seminar participants at CESifo, the University of Heidelberg, the 71st Annual Conference of the MPSA, and the 2014 Meeting of the EPCS also provided valuable feedback.

\section{References}

Abadie, A. (2005). Semiparametric difference-in-differences estimators, Review of Economic Studies 72(1): 1-19.

Alesina, A., Baquir, R. and Easterly, W. (2000). Redistributive public employment, Journal of Urban Economics 48(2): 219-41.

Alesina, A., Danninger, S. and Rostagno, M. (2001). Redistribution through public employment: The case of italy, IMF Staff Papers 48(3).

Arulampalam, W., Dasgupta, S., Dhillon, A. and Dutta, B. (2009). Electoral goals and center-state transfers: A theoretical model and empirical evidence from India, Journal of Development Economics 88(1): 103-119.

Austin, P. (2009). Balance diagnostics for comparing the distribution of baseline covariates between treatment groups in propensity-score matched samples, Statistics in Medicine 28(25): $3083-107$.

Austin, P. (2011). A tutorial and case study in propensity score analysis: An application to estimating the effect of in-hospital smoking cessation counseling on mortality, Multivariate Behavioral Research 46(1): 119-51.

Bhatti, Y. and Hansen, K. (2013). Public employees lining up at the polls - The conditional effect of living and working in the same municipality, Public Choice 156(3): 611-629.

Boix, C. (1998). Political Parties, Growth and Equality. Conservative and Social Democratic Economic Strategies in the World Economy, Cambridge: Cambridge University Press. 
Boso, A., Muñoz, J. and Pallarés, F. (2005). The Spanish general elections 2004. Informe de las Comunidades Autónomas 2004, Barcelona: Instituto de Derecho Público.

Brender, A. (2003). The effect of fiscal performance on local government election results in israel: 1989-1998, Journal of Public Economics 87((9-10)): 2187-2205.

Brender, A. and Drazen, A. (2008). How do budget deficits and economic growth affect reelection prospects? Evidence from a large panel of countries, The American Economic Review 98(5): 2203-2220.

Breton, A. and Wintrobe, R. (1975). The equilibrium size of a budget-maximizing bureau: A note on Niskanen's theory of bureaucracy, Journal of Political Economy 83(1): 195-208.

Bruhn, K. (1996). Social spending and political support: The 'lessons' of the national solidarity program in Mexico, Comparative Politics 28(2): 151-177.

Brusco, V., Nazareno, M. and Stokes, S. (2004). Vote buying in Argentina, Latin American Research Review 39(2): 66-88.

Buchanan, J. (1977). Budgets and Bureaucrats: the Sources of Government Growth, Durham, chapter Why does government grow?

Burgess, R., Jedwab, R., Miguel, E., Morjaria, A. and Padró i Miquel, G. (2015). The value of democracy: Evidence from road building in Kenya, American Economic Review 105(6): 1817-51.

Calvo, E. and Murillo, M. (2004). Who delivers? Partisan clients in the Argentine electoral market, American Journal of Political Science 48(4): 742-757.

Cazorla, J. (1995). El clientelismo de partido en la España de hoy: Una disfunción de la democracia, Revista de Estudios Políticos 86: 35-51.

CEOE, I. (2011). El traspaso de competencias en el sector público.

Chang, C. and Turnbull, G. K. (2002). Bureaucratic behavior in the local public sector: A revealed preference approach, Public Choice 113(1): 191-209.

Chubb, J. (1981). The social bases of an urban political machine: The case of Palermo, Political Science Quarterly 96(1): 107-125. 
Chubb, J. (1982). Patronage, Power, and Poverty in Southern Italy, New York: Cambridge University Press.

Corey, E. and Garand, J. (2002). Are government employees more likely to vote?: An analysis of turnout in the 1996 U.S. national election, Public Choice 111(3): 259-283.

Corzo Fernández, S. (2002). El Clientelismo Político: el Plan de Empleo Rural en Andalucía, un Estudio de Caso, Universidad de Granada.

Courant, P. N., Gramlich, E. M. and Rubinfeld, D. L. (1979). Public employee market power and the level of government spending, American Economic Review 69(5): 806-817.

Dahlberg, M. and Mörk, E. (2006). Public employment and the double role of bureaucrats, Public Choice 126(3/4): 387- 404.

Dahlberg, M. and Mörk, E. (2011). Is there an election cycle in public employment? Separating time effects from election year effects, CESifo Economic Studies 57(3): 480-498.

De La O, A. (2012). Do conditional cash transfers affect electoral behavior? Evidence from a randomized experiment in Mexico, American Journal of Political Science 57(1): 1-14.

Diaz-Cayeros, A., Estevez, F. and Magaloni, B. (2008). Strategies of vote buying: Social transfers, democracy, and poverty reduction in Mexico. Draft manuscript, Stanford Department of Political Science.

Dixit, A. and Londregan, J. (1996). The determinants of success of special interests in redistributive politics, Journal of Politics 58(4): 1132-55.

Drazen, A. and Eslava, M. (2010). Electoral manipulation via voter-friendly spending: Theory and evidence, Journal of Development Economics 92(1): 39-52.

Folke, O., Hirano, S. and Snyder, Jr., J. M. (2011). Patronage and elections in U.S. states, American Political Science Review 105(3): 567-585.

Golden, M. and Min, B. (2013). Distributive politics around the world, Annual Review of Political Science 16: 73-99.

González, J. J. (1990). El desempleo rural en Andalucía y Extremadura, Agricultura y Sociedad 54: 229-266. 
Heckman, J. J., Ichimura, H. and Todd, P. (1997). Matching as an econometric evaluation estimator: Evidence from evaluating a job training programme, Review of Economic Studies 64(4): 605-654.

Heckman, J. J., Ichimura, H. and Todd, P. (1998). Characterizing selection bias using experimental data, Econometrica 66(5): 1017-1098.

Hopkin, J. (2001). A 'Southern model' of electoral mobilisation? Clientelism and electoral politics in Spain, West European Politics 24(1): 115-136.

Hopkin, J. and Mastropaolo, A. (2001). Clientelism, Interests and Democratic Representation, Cambridge: Cambridge University Press, chapter From Patronage to Clientelism: Comparing the Italian and Spanish Experiences.

Jofre-Monseny, J. (2014). The effects of unemployment benefits on migration in lagging regions, Journal of Urban Economics 83: 73-86.

Johnson, R. and Libecap, G. D. (1991). Public sector employee voter participation and salaries, Public Choice 68(1): 137-150.

Katsimi, M. (1998). Explaining the size of the public sector, Public Choice 96(1): 117-144.

Kitschelt, H. and Wilkinson, S. (2007). Patrons, Clients and Policies: Patterns of Democratic Accountability and Political Competition, Cambridge: Cambridge University Press, chapter A Research Agenda.

Labonne, J. (2013). The local electoral impacts of conditional cash transfers: Evidence from a field experiment, Journal of Development Economics 104: 73-88.

Levitt, S. and Snyder, J. (1997). The impact of federal spending on house election outcomes, Journal of Political Economy 105(1): 30-53.

Lindbeck, A. and Weibull, J. W. (1987). Balanced-budget redistribution as the outcome of political competition, Public Choice 52: 237-297.

Manacorda, M., Miguel, E. and Vigorito, A. (2011). Government transfers and political support, American Economic Journal: Applied Economics 3(3): 1-28.

Martín, V. O. (2007). La semifeudalidad y el atraso de España. El ejemplo del Sur., Los libros de la catarata. 
Mattos, E. and França, V. (2011). Public employment and income redistribution: Causal evidence for brazilian municipalities, Public Choice 146: 43-73.

Nazareno, M., Stokes, S. and Brusco, V. (2006). Réditos y peligros electorales del gasto público en la argentina, Desarrollo Económico 46(181): 63-88.

Nichter, S. (2008). Vote buying or turnout buying? machine politics and the secret ballot, American Political Science Review 102(1).

Niskanen, W. (1967). The peculiar economics of bureaucracy, American Economic Review 58(2): 293-305.

Niskanen, W. (1971). Bureaucracy and Representative Government, Chicago: AldineAtherton.

Niskanen, W. (2001). The Elgar Companion to Public Choice, Cheltenham, UK and Northampton, USA: Edward Elgar Publishing, chapter Bureaucracy, pp. 258-270.

Peltzman, S. (1992). Voters as fiscal conservatives, The Quarterly Journal of Economics 107(2): 327-361.

Rattsø, J. and Sørensen, R. (2004). Public employees as swing voters: Empirical evidence on opposition to public reform, Public Choice 119: 281-310.

Robinson, J. A. and Verdier, T. (2013). The political economy of clientelism, Scandinavian Journal of Economics 115(2): 260-291.

Rosenbaum, P. R. and Rubin, D. R. (1984). Reducing bias in observational studies using subclassification on the propensity score, Journal of the American Statistical Association 79(387): 516-24.

Rowe, K., Lago-Peñas, I. and Lago-Peñas, S. (2014). Opening the black box: The partisan consequences of turnout in Portugal and Spain, Comparative European Politics 12.

Sakurai, S. and Menezes-Filho, N. (2008). Fiscal policy and reelection in Brazilian municipalities, Public Choice 137(1): 301-314.

Scoppa, V. (2009). Intergenerational transfers of public sector jobs: a shred of evidence on nepotism, Public Choice 141(1): 167-188. 
Shi, M. and Svensson, J. (2006). Political budget cycles: Do they differ across countries and why?, Journal of Public Economics 90(8-9): 1367-89.

Solé-Ollé, A. and Sorribas-Navarro, P. (2008). The effects of partisan alignment on the allocation of intergovernmental transfers. Differences-in-differences estimates for Spain, Journal of Public Economics 92(12): 2302-2319.

Stokes, S. (2005). Perverse accountability: A formal model of machine politics with evidence from Argentina, American Political Science Review 99(3): 315-325.

Stuart, E. A., Lee, B. K. and Leacy, F. P. (2013). Prognostic score-based balance measures can be a useful diagnostic for propensity scores in comparative effectiveness research, Journal of Clinical Epidemiology 66(8): 84-90.

Zucco, C. (2011). Conditional cash transfers and voting behavior: Redistribution and clientelism in developing democracies. Unpublished manuscript. Princeton University. 
Table 1: Evolution of the number of contracts and funds assigned to the PER

\begin{tabular}{|c|c|c|c|c|c|}
\hline \multicolumn{5}{|c|}{ Number of employment contracts } & $\begin{array}{c}\text { Annual pesetas per } \\
\text { capita invested }\end{array}$ \\
\hline Year & Andalusia & Extremadura & Total & $\begin{array}{c}\% \text { Benefi- } \\
\text { ciaries }\end{array}$ & Total \\
\hline \hline 1984 & 85,191 & 27,367 & 112,558 & $1.4 \%$ & $5,643.2$ \\
\hline 1985 & 196,939 & 57,598 & 254,537 & $3.2 \%$ & $6,463.1$ \\
\hline 1986 & 212,978 & 73,198 & 286,176 & $3.6 \%$ & $10,217.4$ \\
\hline 1987 & 201,556 & 80,672 & 282,228 & $3.6 \%$ & $11,906.4$ \\
\hline 1988 & 159,913 & 73,387 & 233,300 & $2.9 \%$ & $14,767.4$ \\
\hline 1989 & 151,554 & 65,071 & 216,625 & $2.7 \%$ & $18,620.6$ \\
\hline 1990 & 122,590 & 51,398 & 173,988 & $2.1 \%$ & $19,355.8$ \\
\hline 1991 & 113,077 & 47,866 & 160,943 & $2.0 \%$ & $25,166.6$ \\
\hline 1992 & 94,357 & 43,937 & 138,294 & $1.7 \%$ & $23,627.2$ \\
\hline 1993 & 111,830 & 50,576 & 162,406 & $2.0 \%$ & $25,501.7$ \\
\hline
\end{tabular}

Source: Spanish Congress. Doc. 61, Serie E. 18 May 1994.

Notes: \% Beneficiaries (column 5) refers to the percentage of the population in Andalusia and Extremadura who benefited from a PER contract. The last column refers to annual investment per capita related to PER projects. Values are in 1984 pesetas (CPI-deflated). That year, 1 USD $=163.651$ pesetas. 
Table 2: Socioeconomic indicators of the Spanish regions in the early 1980s

\begin{tabular}{|c|c|c|c|c|c|}
\hline Region & $\begin{array}{c}\text { Density } \\
\left(\mathbf{p o p} / \mathrm{km}^{2}\right)\end{array}$ & $\begin{array}{c}\text { Agrarian } \\
\text { production }\end{array}$ & $\begin{array}{c}\text { Relative } \\
\text { per-capita } \\
\text { GDP }\end{array}$ & Unemployment & $\begin{array}{c}\text { Agricultural } \\
\text { unemployment }\end{array}$ \\
\hline \multicolumn{6}{|c|}{ Regions affected by the PER } \\
\hline Andalusia & 73.53 & $11.21 \%$ & $75 \%$ & $22.41 \%$ & $3.01 \%$ \\
\hline Extremadura & 25.22 & $17.05 \%$ & $58 \%$ & $16.34 \%$ & $1.70 \%$ \\
\hline \multicolumn{6}{|c|}{ Regions not affected by the PER } \\
\hline Aragon & 25.42 & $8.10 \%$ & $103 \%$ & $13.69 \%$ & $0.25 \%$ \\
\hline Balearic Islands & 137.25 & $3.07 \%$ & $115 \%$ & $13.94 \%$ & $0.02 \%$ \\
\hline Basque Country & 295.06 & $0.84 \%$ & $131 \%$ & $19.61 \%$ & $0.21 \%$ \\
\hline Canary Islands & 193.98 & $5.25 \%$ & $93 \%$ & $19.11 \%$ & $0.79 \%$ \\
\hline Cantabria & 95.99 & $0.6 \%$ & $107 \%$ & $12.60 \%$ & $0.18 \%$ \\
\hline Castile-La Mancha & 20.47 & $16.03 \%$ & $80 \%$ & $14.08 \%$ & $1.58 \%$ \\
\hline Castile-Leon & 27.33 & $7.60 \%$ & $90 \%$ & $13.56 \%$ & $0.52 \%$ \\
\hline Catalonia & 185.54 & $2.50 \%$ & $114 \%$ & $21.07 \%$ & $0.19 \%$ \\
\hline Galicia & 93.11 & $3.35 \%$ & $84 \%$ & $9.89 \%$ & $0.19 \%$ \\
\hline La Rioja & 50.21 & $12.20 \%$ & $118 \%$ & $11.28 \%$ & $0.05 \%$ \\
\hline Madrid & 588.84 & $0.33 \%$ & $119 \%$ & $16.70 \%$ & $0.07 \%$ \\
\hline Navarre & 48.83 & $6.93 \%$ & $127 \%$ & $15.51 \%$ & $0.27 \%$ \\
\hline Principality of Asturias & 106.28 & $1.27 \%$ & $94 \%$ & $13.90 \%$ & $0.08 \%$ \\
\hline Region of Murcia & 84.67 & $9.25 \%$ & $91 \%$ & $16.62 \%$ & $1.62 \%$ \\
\hline Valencian Community & 156.82 & $6.56 \%$ & $101 \%$ & $17.27 \%$ & $0.40 \%$ \\
\hline
\end{tabular}

\section{Notes:}

(1) Definitions: density (population density, in 1981); agrarian production (agricultural production/GDP, in 1982), relative per-capita GDP (regional GDP/national GDP, in 1982); unemployment (unemployed workers/total labor force, in 1983), agricultural unemployment (agricultural unemployed workers/ total labor force, in 1983).

(2) Data sources: population density (Estadísticas Históricas de España, Siglos XIX-XX, (Bilbao: Fundación BBVA, 2005)); agrarian production (Anuario de Estadística Agraria); relative per-capita GDP (regional accounts, INE); total and agricultural unemployment (Economically Active Population Survey, INE). 
Table 3: Determinants of the distribution of PER beneficiaries (Granada, 1998-2007)

\begin{tabular}{|c|c|c|c|c|c|c|}
\hline & $(1)$ & $(2)$ & $(3)$ & $(4)$ & $(5)$ & (6) \\
\hline Unemployment & $\begin{array}{c}0.223^{* * *} \\
(0.035)\end{array}$ & $\begin{array}{c}0.222^{* * *} \\
(0.036)\end{array}$ & $\begin{array}{c}0.215^{* * *} \\
(0.036)\end{array}$ & $\begin{array}{l}0.087^{*} \\
(0.049)\end{array}$ & & \\
\hline Agrarian & & $\begin{array}{c}0.004 \\
(0.007)\end{array}$ & & & & $\begin{array}{c}0.010 \\
(0.011)\end{array}$ \\
\hline Rural & & & $\begin{array}{c}0.016^{* *} \\
(0.007)\end{array}$ & $\begin{array}{c}0.004 \\
(0.006)\end{array}$ & $\begin{array}{c}0.014 \\
(0.009)\end{array}$ & \\
\hline High unemployment & & & & & $\begin{array}{c}0.038^{* * *} \\
(0.013)\end{array}$ & $\begin{array}{c}0.059 * * * \\
(0.010)\end{array}$ \\
\hline High unemployment $\times$ Rural & & & & & $\begin{array}{c}0.011 \\
(0.014)\end{array}$ & \\
\hline High unemployment $\times$ Agrarian & & & & & & $\begin{array}{l}-0.017 \\
(0.014)\end{array}$ \\
\hline Political alignment & $\begin{array}{l}-0.006 \\
(0.004)\end{array}$ & $\begin{array}{l}-0.006 \\
(0.004)\end{array}$ & $\begin{array}{l}-0.006 \\
(0.004)\end{array}$ & $\begin{array}{c}-0.002 \\
(0.003)\end{array}$ & $\begin{array}{l}-0.005 \\
(0.004)\end{array}$ & $\begin{array}{l}-0.005 \\
(0.004)\end{array}$ \\
\hline Socialist mayor & $\begin{array}{c}0.000 \\
(0.005)\end{array}$ & $\begin{array}{l}-0.000 \\
(0.005)\end{array}$ & $\begin{array}{c}0.001 \\
(0.005)\end{array}$ & $\begin{array}{c}0.004 \\
(0.005)\end{array}$ & $\begin{array}{c}0.001 \\
(0.006)\end{array}$ & $\begin{array}{l}-0.001 \\
(0.006)\end{array}$ \\
\hline Secondary education & $\begin{array}{c}-0.171^{* * *} \\
(0.043)\end{array}$ & $\begin{array}{c}-0.165^{* * *} \\
(0.044)\end{array}$ & $\begin{array}{c}-0.149 * * * \\
(0.045)\end{array}$ & $\begin{array}{c}0.035 \\
(0.098)\end{array}$ & $\begin{array}{c}-0.189^{* * *} \\
(0.045)\end{array}$ & $\begin{array}{c}-0.197^{* * *} \\
(0.042)\end{array}$ \\
\hline Tertiary education & $\begin{array}{c}-0.289^{* * *} \\
(0.079)\end{array}$ & $\begin{array}{c}-0.280 * * * \\
(0.080)\end{array}$ & $\begin{array}{c}-0.272^{* * *} \\
(0.078)\end{array}$ & $\begin{array}{c}0.013 \\
(0.227)\end{array}$ & $\begin{array}{c}-0.352^{* * *} \\
(0.093)\end{array}$ & $\begin{array}{c}-0.353^{* * *} \\
(0.094)\end{array}$ \\
\hline Population growth & $\begin{array}{c}-0.149^{* * *} \\
(0.057)\end{array}$ & $\begin{array}{c}-0.148^{* *} \\
(0.057)\end{array}$ & $\begin{array}{c}-0.115^{* *} \\
(0.056)\end{array}$ & $\begin{array}{l}-0.026 \\
(0.043)\end{array}$ & $\begin{array}{c}-0.142^{* *} \\
(0.061)\end{array}$ & $\begin{array}{c}-0.177^{* * *} \\
(0.063)\end{array}$ \\
\hline Constant & $\begin{array}{c}0.150^{* * *} \\
(0.028)\end{array}$ & $\begin{array}{c}0.146^{* * *} \\
(0.028)\end{array}$ & $\begin{array}{c}0.131^{* * *} \\
(0.030)\end{array}$ & $\begin{array}{l}0.090^{*} \\
(0.052)\end{array}$ & $\begin{array}{c}0.207^{* * *} \\
(0.024)\end{array}$ & $\begin{array}{c}0.216^{* * *} \\
(0.020)\end{array}$ \\
\hline Year fixed effects & Yes & Yes & Yes & Yes & Yes & Yes \\
\hline Municipality fixed effects & No & No & No & Yes & No & No \\
\hline Observations & 1,664 & 1,664 & 1,664 & 1,664 & 1,664 & 1,664 \\
\hline R-squared & 0.483 & 0.484 & 0.488 & 0.165 & 0.462 & 0.458 \\
\hline Number of clusters & 168 & 168 & 168 & 168 & 168 & 168 \\
\hline Mean dependent variable & 0.101 & 0.101 & 0.101 & 0.101 & 0.101 & 0.101 \\
\hline
\end{tabular}

Notes: (1) Dependent variable: number of PER beneficiaries as a percentage of the working-age population; (2) the data refer to the province of Granada over the 1998-2007 period; (3) robust standard errors in parentheses, $* * * \mathrm{p}<0.01$, ${ }^{* *} \mathrm{p}<0.05,{ }^{*} \mathrm{p}<0.1$; (4) SE clustered by municipality; (5) Rural is a binary variable equal to one if the population density is fewer than 100 inhabitants per square kilometer and the municipality has fewer than 5,000 inhabitants; Unemployment refers to the unemployment rate; High Unemployment is a binary variable equal to one if the unemployment rate of a municipality is above the average; Agrarian is a binary variable equal to one if the units of temporary wage labor per capita in the agricultural sector are above the average; Political alignment indicates whether a municipality's mayor is a member of the party ruling at the central government level; Socialist mayor is a binary variable that equals one if the mayor is affiliated with the PSOE; Secondary Education and Tertiary Education are the percentage of people with secondary and tertiary education, respectively. 
Table 4: Probit estimates to obtain the matched sample

\begin{tabular}{lcc}
\hline & Coefficient & z-statistic \\
\hline Education (\%) & 1.571 & $(2.48)^{* *}$ \\
Population growth (\%) & -2.232 & $(-3.89)^{* * *}$ \\
Unemployment (\%) & 5.302 & $(21.11)^{* * *}$ \\
Population size & 0.000 & $(13.62)^{* * *}$ \\
Population density & 0.016 & $(8.46)^{* * *}$ \\
Constant & -2.729 & $(-20.27)^{* * *}$ \\
& & \\
Pseudo-R-squared & & 0.344 \\
\hline $\begin{array}{l}\text { Note: (1) The dependent variable is a dummy equal to one if a municipality is in the } \\
\text { region of Andalusia or Extremadura and zero otherwise; (2) N=3,592 municipalities. }\end{array}$
\end{tabular}


Table 5: Covariate balance across the treatment and control regions before PER introduction

\begin{tabular}{|c|c|c|c|c|c|c|}
\hline \multirow{2}{*}{ Variable } & \multicolumn{3}{|c|}{ Original sample } & \multicolumn{3}{|c|}{ Matched sample } \\
\hline & $\begin{array}{c}\text { Mean } \\
\text { treatment }\end{array}$ & $\begin{array}{l}\text { Mean } \\
\text { control }\end{array}$ & $\begin{array}{c}\text { Standardized } \\
\text { difference } \\
(\%)\end{array}$ & $\begin{array}{c}\text { Mean } \\
\text { treatment }\end{array}$ & $\begin{array}{l}\text { Mean } \\
\text { control }\end{array}$ & $\begin{array}{c}\text { Standardized } \\
\text { difference } \\
(\%)\end{array}$ \\
\hline Unemployment (\%) & 0.24 & 0.09 & $122.3^{*}$ & 0.24 & 0.24 & -2.0 \\
\hline Education (\%) & 0.17 & 0.16 & $20.8^{*}$ & 0.17 & 0.17 & 3.3 \\
\hline Population growth (\%) & -0.04 & -0.05 & 8.7 & -0.04 & -0.04 & 1.0 \\
\hline Population density & 28.5 & 14.9 & $80.8^{*}$ & 27.9 & 27.7 & 1.4 \\
\hline Population size & 1650.9 & 636.6 & $106.7^{*}$ & 1617.4 & 1561.7 & 5.9 \\
\hline
\end{tabular}

Notes: (1) * The absolute value of the mean standardized difference is above $10 \%$; 2 ) the sample contains only rural towns; (3) the treatment group includes Andalusia and Extremadura while the control group includes Murcia, Castile-La Mancha, and Castile-Leon. 
Table 6: Program effects on the support for the Socialist Party (PSOE)

\begin{tabular}{lcccc}
\hline & $(1)$ & $(2)$ & $(3)$ & $(4)$ \\
& DiD & DiD & $\begin{array}{c}\text { DiD } \\
\text { matching }\end{array}$ & $\begin{array}{c}\text { DiD } \\
\text { matching }\end{array}$ \\
& & & & \\
PER & & & & \\
& $\left(0.041^{* * *}\right.$ & $0.043^{* * *}$ & $0.039^{* * *}$ & $0.038^{* * *}$ \\
& & $(0.004)$ & $(0.005)$ & $(0.006)$ \\
R-squared & 0.474 & 0.484 & 0.554 & 0.558 \\
Observations & 21,552 & 21,552 & 21,468 & 21,468 \\
Socioeconomic controls & No & Yes & Yes & Yes \\
Year and municipality fixed effects & Yes & Yes & Yes & Yes \\
Region $\times$ time trends & No & Yes & No & Yes \\
Joint significance region $\times$ time & & 6.33 & & 2.60 \\
trends (p-value) & & $(0.034)$ & & $(0.034)$ \\
\hline
\end{tabular}

Notes: (1) robust standard errors in parentheses, ${ }^{* * *} \mathrm{p}<0.01,{ }^{* *} \mathrm{p}<0.05,{ }^{*} \mathrm{p}<0.1 ;(2)$ SE clustered by municipality; (3) dependent variable: The Socialist Party vote share in general elections over the period 1979-1996; (4) PER is a binary variable that indicates treatment; (5) the socioeconomic controls included are population growth, percentage of retired workers, an indicator of education level, unemployment rates, population size, and population density; (6) columns 1 and 2 show difference-in-differences estimates, while the regression technique in columns 3 and 4 combines difference-in-differences with propensity score matching. 
Table 7: Program effects on voter turnout

\begin{tabular}{lcccc}
\hline & $(1)$ & $(2)$ & $(3)$ & $(4)$ \\
& DiD & DiD & $\begin{array}{c}\text { DiD } \\
\text { matching }\end{array}$ & $\begin{array}{c}\text { DiD } \\
\text { matching }\end{array}$ \\
& & & & \\
PER & & & & \\
& $0.029^{* * *}$ & $-0.018^{* * *}$ & $0.025^{* * *}$ & -0.002 \\
& $(0.002)$ & $(0.003)$ & $(0.003)$ & $(0.004)$ \\
R-squared & & & & \\
Observations & 0.404 & 0.447 & 0.596 & 0.605 \\
Socioeconomic controls & 21,552 & 21,552 & 21,468 & 21,468 \\
Year and region fixed effects & No & Yes & Yes & Yes \\
Region $\times$ time trends & Yes & Yes & Yes & Yes \\
Joint significance region $\times$ time & No & Yes & No & Yes \\
trends (p-value) & & 86.00 & & 27.99 \\
\hline
\end{tabular}

Notes: (1) robust standard errors in parentheses, ${ }^{* * *} \mathrm{p}<0.01,{ }^{* *} \mathrm{p}<0.05,{ }^{*} \mathrm{p}<0.1$; (2) SE clustered by municipality; (3) dependent variable: voter turnout in general elections over the 1979-1996 period; (4) PER is a binary variable that indicates treatment; (5) the socioeconomic controls included are population growth, percentage of retired workers, an indicator of education level, unemployment rates, population size, and population density; (6) columns 1 and 2 show difference-in-differences estimates, while the regression technique in columns 3 and 4 combines difference-in-differences with propensity score matching. 
Table 8: Additional results. Program effects on the support for opposition parties. Differencein-differences matching estimates

\begin{tabular}{|c|c|c|c|c|}
\hline & $(1)$ & $(2)$ & $(3)$ & $(4)$ \\
\hline Dependent variable & $\begin{array}{l}\text { \% People's } \\
\text { Party vote }\end{array}$ & $\begin{array}{l}\% \text { People's } \\
\text { Party vote }\end{array}$ & $\begin{array}{c}\quad \% \\
\text { Communist } \\
\text { Party vote }\end{array}$ & $\begin{array}{c}\% \\
\text { Communist } \\
\text { Party vote }\end{array}$ \\
\hline PER & $\begin{array}{c}-0.057^{* * *} \\
(0.005)\end{array}$ & $\begin{array}{l}-0.007 \\
(0.011)\end{array}$ & $\begin{array}{c}0.004 \\
(0.003)\end{array}$ & $\begin{array}{c}0.013^{* * *} \\
(0.002)\end{array}$ \\
\hline R-squared & 0.786 & 0.795 & 0.202 & 0.221 \\
\hline Observations & 21,468 & 21,228 & 21,228 & 21,228 \\
\hline Socioeconomic controls & Yes & Yes & Yes & Yes \\
\hline Year and municipality fixed effects & Yes & Yes & Yes & Yes \\
\hline Region $\times$ time trends & No & Yes & No & Yes \\
\hline $\begin{array}{l}\text { Joint significance region } \times \text { time } \\
\text { trends }(\mathrm{p} \text {-value })\end{array}$ & & $\begin{array}{l}128.13 \\
(0.000)\end{array}$ & & $\begin{array}{c}25.55 \\
(0.000)\end{array}$ \\
\hline
\end{tabular}

Notes: (1) robust standard errors in parentheses, ${ }^{* * *} \mathrm{p}<0.01,{ }^{* *} \mathrm{p}<0.05,{ }^{*} \mathrm{p}<0.1 ;$ (2) SE clustered by municipality; (3) dependent variables: People's Party vote share (column 1 and 2) and Communist Party vote share (columns 3 and 4) in general elections during the period 1979-1996; (4) PER is a binary variable that indicates treatment; (5) the socioeconomic controls included are population growth, percentage of retired workers, an indicator of education level, unemployment rates, population size, and population density; (6) all estimates are obtained from regressions that combine difference-in-differences with propensity score matching. 
Table 9: Program effects over the years 1979-1996. Matching difference-in-differences estimates

Dependent variable

\% Socialist Party \% Communist Party

vote

vote

\begin{tabular}{lcc} 
PER & $0.043^{* * *}$ & $0.009^{* * *}$ \\
& $(0.005)$ & $(0.003)$ \\
PER $\times 1989$ Election & -0.004 & $-0.004^{* *}$ \\
& $(0.005)$ & $(0.002)$ \\
PER $\times 1993$ Election & -0.001 & $-0.010^{* * *}$ \\
& $(0.004)$ & $(0.003)$ \\
PER $\times 1996$ Election & $-0.010^{* *}$ & $-0.009^{* * *}$ \\
& $(0.004)$ & $(0.002)$ \\
R-squared & & 0.205 \\
Observations & 0.555 & 21,468 \\
Socioeconomic controls & 21,468 & Yes \\
Year and municipality fixed effects & Yes & Yes \\
\hline
\end{tabular}

Notes: (1) robust standard errors in parentheses, ${ }^{* * *} \mathrm{p}<0.01,{ }^{* *} \mathrm{p}<0.05,{ }^{*} \mathrm{p}<0.1$; (2) SE clustered by municipality; (3) dependent variables: Socialist Party vote share (column 1) and Communist Party vote share (column 2) in general elections during the 1979-1996 period; (4) 1989Election, 1993Election, and 1996Election are time dummies indicating the election years (the reference year is the first year after the PER introduction, i.e., 1986); (5) the socioeconomic controls included are population growth, percentage of retired workers, an indicator of education level, unemployment rates, population size, and population density; (6) all estimates are obtained from regressions that combine differencein-differences with propensity score matching. 
Table 10: Falsification tests. ATT effects in urban municipalities

\begin{tabular}{lcccc}
\hline & $(1)$ & $(2)$ & $(3)$ & $(4)$ \\
Dependent variable & $\begin{array}{c}\text { \% PSOE } \\
\text { vote }\end{array}$ & Turnout & $\%$ PP vote & $\begin{array}{c}\% \text { PCE } \\
\text { vote }\end{array}$ \\
\hline PER & & & & \\
& 0.019 & 0.007 & 0.004 & 0.009 \\
& $(0.012)$ & $(0.010)$ & $(0.010)$ & $(0.009)$ \\
R-squared & 0.689 & 0.633 & 0.915 & 0.513 \\
Observations & 1,164 & 1,164 & 1,164 & 1,164 \\
Socioeconomic controls & Yes & Yes & Yes & Yes \\
$\begin{array}{l}\text { Year and municipality fixed } \\
\text { effects }\end{array}$ & Yes & Yes & Yes & Yes \\
Region $\times$ time trends & Yes & Yes & Yes & Yes \\
\hline
\end{tabular}

Notes: (1) robust standard errors in parentheses, ${ }^{* * *} \mathrm{p}<0.01,{ }^{*} \mathrm{p}<0.05,{ }^{*} \mathrm{p}<0.1 ;$ (2) SE clustered by municipality; (3) dependent variables: Socialist Party vote share (column 1), voter turnout (column 2), People's Party vote share (column 3), and Communist Party vote share (column 4) in general elections during the years 1979-1996; (4) PER is a binary variable that indicates treatment; (5) the socioeconomic controls included are population growth, percentage of retired workers, an indicator of education level, unemployment rates, population size, and population density; (6) all estimates are obtained from regressions that combine difference-in-differences with propensity score matching; (7) the sample is restricted to urban municipalities with population density and size over 100 and 5,000, respectively. 
Table 11: Robustness test: effects of immigration from neighboring regions

\begin{tabular}{lcc} 
Dependent variable & $\begin{array}{c}\text { Electoral } \\
\text { census }\end{array}$ & $\begin{array}{c}\text { Electoral } \\
\text { census }\end{array}$ \\
\hline PER & & \\
& $(6.884)$ & $(8.487)$ \\
& & \\
R-squared & 0.651 & 0.656 \\
Observations & 21,468 & 21,468 \\
Socioeconomic controls & Yes & Yes \\
Year and municipality fixed effects & Yes & Yes \\
Region $\times$ time trends & Yes & Yes \\
\hline
\end{tabular}

Notes: (1) robust standard errors in parentheses, ${ }^{* * *} \mathrm{p}<0.01,{ }^{*} \mathrm{p}<0.05,{ }^{*} \mathrm{p}<0.1$; (2) SE clustered by municipality; (3) dependent variables: Socialist Party vote share (column 1 ) and voter turnout (column 2) in general elections during the years 1979-1996; (4) PER is a binary variable that indicates treatment; (5) the socioeconomic controls included are population growth, percentage of retired workers, an indicator of education level, unemployment rates, population size, and population density; (6) all estimates are obtained from regressions that combine differencein-differences with propensity score matching. 
Table 12: Additional test: effects of the decentralization process

\begin{tabular}{lcccc}
\hline & $(1)$ & $(2)$ & $(3)$ & $(4)$ \\
Dependent variable & $\begin{array}{c}\text { \% PSOE } \\
\text { vote }\end{array}$ & Turnout & \% PP vote & $\begin{array}{c}\% \text { PCE } \\
\text { vote }\end{array}$ \\
\hline & & & & \\
PER & $0.038^{* * *}$ & -0.004 & -0.009 & $0.013^{* * *}$ \\
& $(0.007)$ & $(0.004)$ & $(0.011)$ & $(0.002)$ \\
Education centers & -0.006 & 0.004 & -0.010 & 0.000 \\
& $(0.009)$ & $(0.005)$ & $(0.008)$ & $(0.003)$ \\
R-squared & & & & 0.221 \\
Observations & 0.558 & 0.590 & 0.793 & 21,468 \\
Socioeconomic controls & 21,468 & 21,468 & 21,468 & Yes \\
Year and municipality fixed \\
effects
\end{tabular}

Notes: (1) robust standard errors in parentheses, ${ }^{* * *} \mathrm{p}<0.01,{ }^{* *} \mathrm{p}<0.05,{ }^{*} \mathrm{p}<0.1$; (2) SE clustered by municipality; (3) dependent variables: Socialist Party vote share (column 1), voter turnout (column 2), People's Party vote share (column 3), and Communist Party vote share (column 4) in general elections during the years 1979-1996; (4) PER is a binary variable that indicates treatment; (5) the additional controls included are population density, population size, and population growth; (6) all estimates are obtained from regressions that combine difference-in-differences with propensity score matching. 
Figure 1: Treatment and control regions

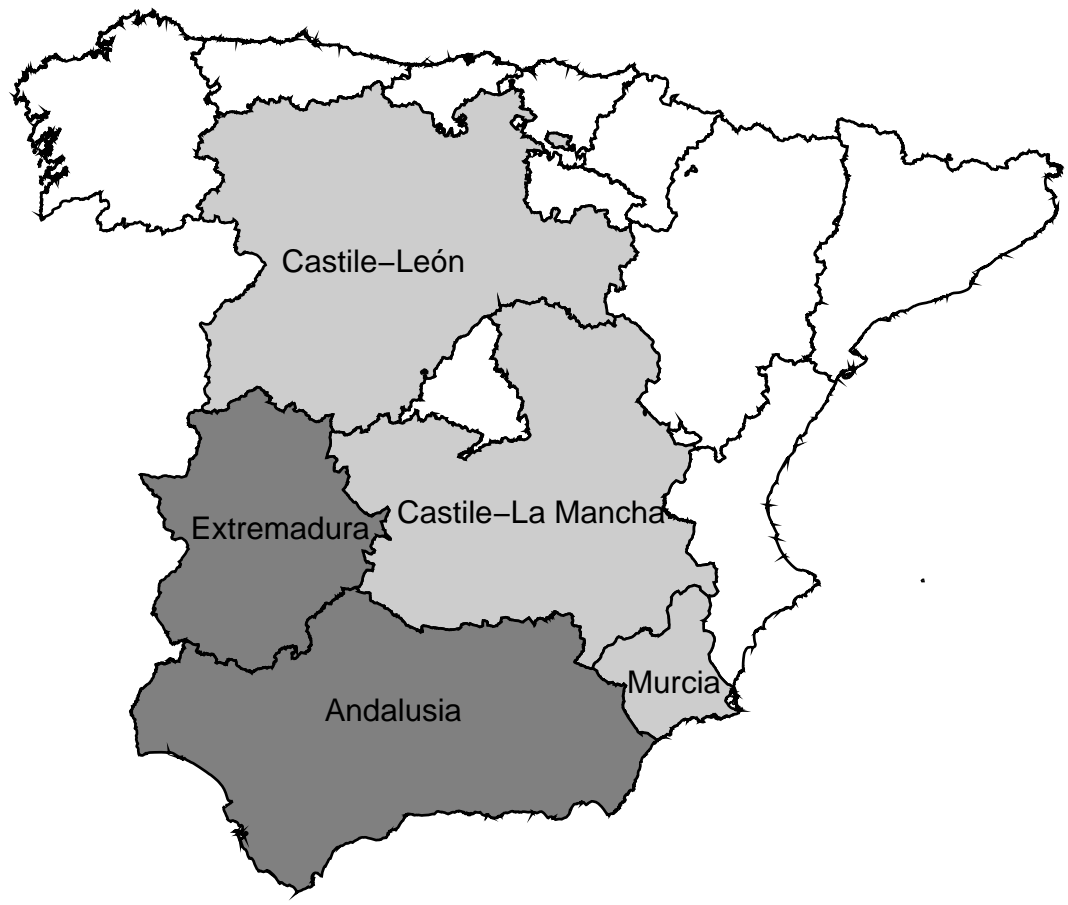

Note: Andalusia and Extremadura are the two regions that have been affected by the PER since 1984. Castile-La Mancha, Castile-Leon, and Murcia are used as the control regions in this study. 
Figure 2: Distribution of the propensity score across treated and control municipalities

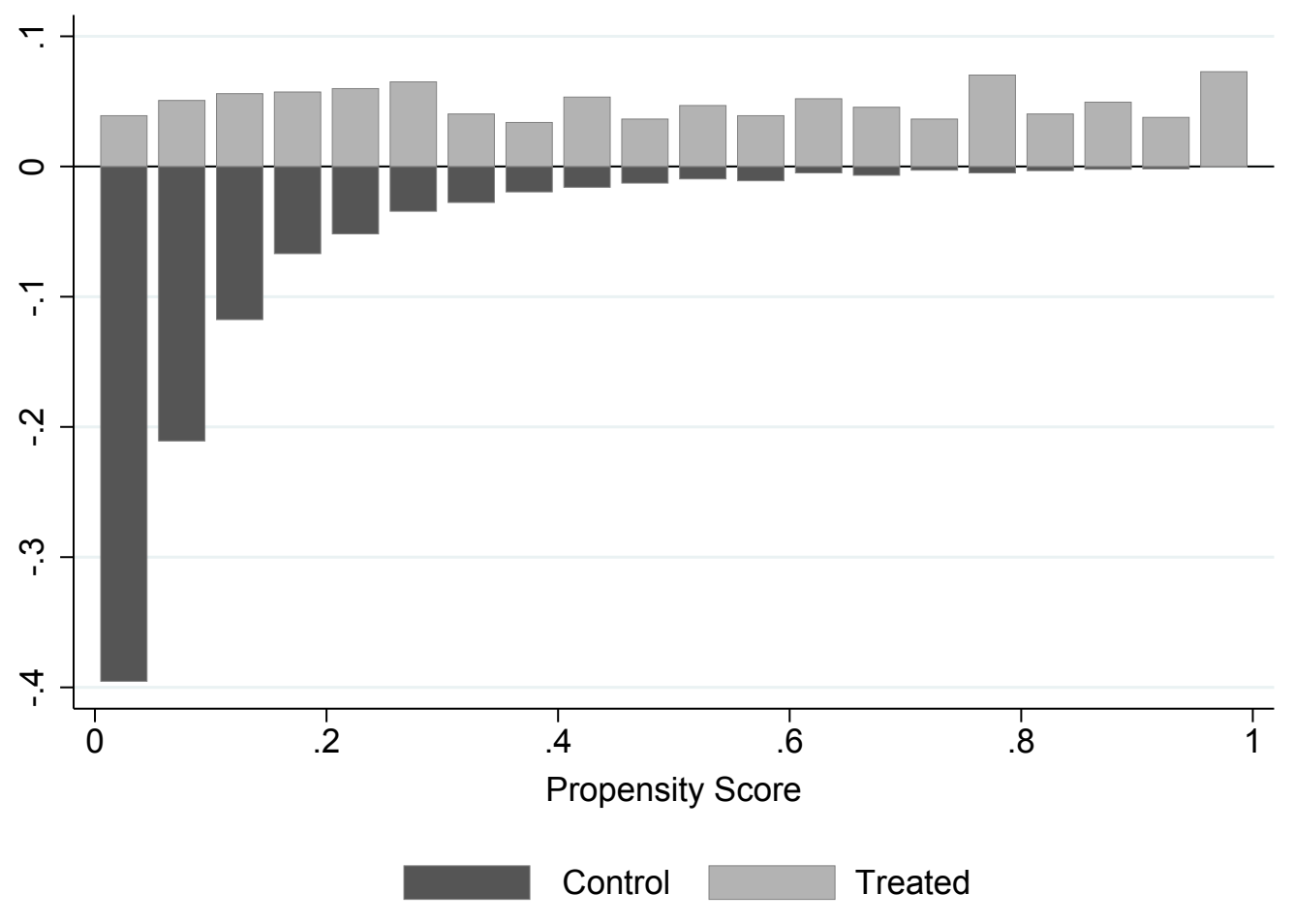

